\title{
Proliferation is not increased in airway myofibroblasts isolated from asthmatics
}

\author{
J.E. Ward*^, T. Harris*,§, T. Bamford*, A. Mast*, M.C.F. Pain”, C. Robertson \\ D. Smallwood ${ }^{\#}$, T. Tran*, J. Wilson ${ }^{+}$and A.G. Stewart*
}

ABSTRACT: Airway mesenchymal cells, such as myofibroblasts and airway smooth muscle cells, contribute to inflammation, airway remodelling and hyperresponsiveness in asthma by excessive proliferation and inflammatory mediator production.

Using endobronchial biopsies obtained from both nonasthmatic and asthmatic subjects, in situ proliferation was assessed by immunostaining for cyclin D1. The number of immunoreactive cells increased with asthma severity and was restricted to the epithelium and subepithelial connective tissue. Despite increases in smooth muscle area, cyclin D1 was not detected in cells in intact muscle bundles.

Biopsy-derived cell cultures were characterised as predominantly myofibroblasts, and were assessed to determine whether proliferation and cytokine production varied with asthma status. Cell enumeration showed that basal proliferation was similar in cells from nonasthmatics and asthmatics, and mitogenic responses to fibroblast growth factor-2, thrombin or serum were either reduced or unchanged in cells from asthmatics. Interleukin (IL)-1-dependent granulocytemacrophage colony-stimulating factor and IL-8 release was increased in cell supernatants from asthmatics.

Thus, increased rates of cellular proliferation identified in situ in the asthmatic airway occurred outside the expanded smooth muscle compartment. Although reduced proliferative responses were observed in cultured myofibroblasts from asthmatics, the increased cytokine production by these cells suggests that this contributes to and may perpetuate ongoing inflammation in asthma.

KEYWORDS: Airway smooth muscle, asthma, fluticasone propionate, myofibroblast, proliferation, salmeterol

$\mathrm{T}$ he asthmatic airway wall is characterised by tissue remodelling in which epithelial disruption, goblet cell hyperplasia, reticular basement membrane thickening, airway mesenchymal (smooth muscle and myofibroblast) cell hypertrophy and/or hyperplasia and subepithelial collagen deposition are major features that contribute to airway hyperresponsiveness [1, 2].

Cultured human airway smooth muscle cells and myofibroblasts produce multiple inflammatory mediators and proliferate in response to cytokines and polypeptide growth factors [3, 4]. Airway smooth muscle cultured from asthmatics is claimed to be hyperproliferative with $5 \%$ foetal calf serum (FCS) [5] but refractory to the antiproliferative effects of glucocorticoids [6]. Similar findings are reported with myofibroblasts using ${ }^{3} \mathrm{H}$-thymidine incorporation, a marker of cells in S-phase or DNA repair [7-9]. Thrombin and fibroblast growth factor (FGF)-2, which are at elevated bronchoalveolar lavage (BAL) concentrations in asthma, are mitogenic for both myofibroblasts and airway smooth muscle [1012]. However, it is not known whether asthma status influences the proliferative responses of airway mesenchymal cells to these specific mitogens.

Interleukin (IL)-1 can elicit the release of granulocyte-macrophage colony-stimulating factor (GM-CSF) [13, 14] and IL-8 [15] from myofibroblasts and airway smooth muscle. These cytokines play important roles in promoting recruitment, maturation and survival of eosinophils, mast cells and neutrophils, while GM-CSF may also contribute to subepithelial fibrosis by regulating collagen deposition [16]. Asthma-associated changes in the production of these inflammatory mediators have not been
AFFILIATIONS

*Dept of Pharmacology, University of Melbourne,

"Dept of Thoracic Medicine, Royal Melbourne Hospital,

"Dept of Respiratory Medicine, Royal Children's Hospital, and,

+Dept of Medicine, Monash

University, Melbourne, Australia.

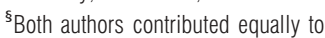
this article.

CORRESPONDENCE

A.G. Stewart

Dept of Pharmacology

University of Melbourne

Melbourne

Victoria 3010

Australia

Fax: 61383440241

E-mail: astew@unimelb.edu.au

Received:

September 092007

Accepted after revision:

March 022008

SUPPORT STATEMENT

This study received financial support from the National Health and Medical

Research Council (Canberra,

Australia), grants 299823 and 509239 .

\section{STATEMENT OF INTEREST}

Statements of interest for J. Wilson and A.G. Stewart can be found at www.erj.ersjournals.com/misc/ statements.shtml 
fully explored, although there are unconfirmed reports showing increased release of eotaxin [17] and connective tissue growth factor [18] from airway smooth muscle cultured from asthmatics.

In the present study, endobronchial biopsies were obtained from healthy nonasthmatic volunteers and from patients with varying asthma severity. The majority of subjects (81 out of 92) were recruited at 42 yrs of age from a cohort in a long-term study (Melbourne Epidemiological Study of Childhood Asthma (MESCA)), in which data has been collected every 7 yrs from participants since they were 7 yrs of age $[19,20]$. Initial immunohistochemical studies revealed an asthma severity-related increase in the frequency of cyclin D1-positive cells, a marker of proliferation [21]. However, despite a significant increase in smooth muscle area, no evidence was found for ongoing proliferation of mesenchymal cells within the muscle bundles at the time of biopsy [22]. Therefore, in the present study, cell cultures were established from a subset of these biopsies and, after characterising these cells as predominantly myofibroblasts, the relationships were assessed between proliferation or cytokine production and asthma status and the sensitivity of proliferative responses to clinical asthma medications.

\section{MATERIALS AND METHODS}

\section{Subjects}

Subjects were either nonasthmatic or asthmatic volunteers with varying asthma severity recruited from the MESCA cohort ( $n=82$, all aged 42 yrs at the time of biopsy) [19], or steroidrequiring asthmatics recruited from the Royal Melbourne Hospital (Melbourne, Australia; $n=9$, mean (range) age 43 (27-67) yrs). All subjects were stratified using the Global Initiative for Asthma guidelines (table 1) [23] and chronic obstructive pulmonary disease was excluded. Biopsies were obtained using fibreoptic bronchoscopy [24], with approval from Human Experimental Ethics Committees of the Royal Children's and Royal Melbourne Hospitals (Melbourne; maximum permissible was six biopsies per subject). Biopsies from all subjects were fixed for immunohistochemistry and, where available, were also used to establish cell cultures (table 1). Further details are outlined in the online supplementary material.

\section{Immunohistochemistry of biopsies}

The number of cyclin D1-positive cells was counted on $5-\mu \mathrm{m}$ biopsy sections as a measure of cell proliferation, and expressed per $\mathrm{mm}^{2}$ of quantifiable biopsy area, as described previously [24] and in the online supplementary material.

\section{Cell culture}

Cell cultures were established from endobronchial biopsies from a subset of the MESCA cohort (table 1). After removal of the epithelium, the remaining tissue was teased apart, attached to a six-well culture plate and maintained in Dulbecco's modified Eagle medium (DMEM) with $20 \%$ volume (v)/v FCS, $2 \mathrm{mM}$ L-glutamine, $100 \mu \mathrm{g} \cdot \mathrm{mL}^{-1}$ streptomycin, $100 \mathrm{U} \cdot \mathrm{mL}^{-1}$ penicillin-G and $2 \mu \mathrm{g} \cdot \mathrm{mL}^{-1}$ amphotericin. In addition to these cultures, separate airway myofibroblast and smooth muscle cultures were also established from macroscopically normal lung resection tissues as previously described [10]. For all biopsy- and resection-derived cultures, cells were used at passages $4-15$.

\section{Flow cytometry and immunocytochemistry for phenotyping biopsy-derived cells}

In three experiments, properties of airway myofibroblasts and smooth muscle derived from the same resection specimen were compared and subsequently used to phenotype biopsy-derived cells. Morphometric properties were analysed by flow cytometry to determine differences in cell size (by forward scatter; FACS Calibur II; BD, North Ryde, Australia). Expression of mesenchymal cell phenotypic markers was assessed using antibodies to proline-4-hydroxylase, $\alpha$-smooth muscle actin (SMA), myosin and vimentin, as previously described [25]. Airway epithelial cell contamination of cultures was assessed by cytokeratin immunoreactivity. Immunocytochemistry for these phenotypic markers is described in the supplementary material. On the basis of these studies, the biopsy-derived cells were characterised as predominantly myofibroblasts [26].

\section{Proliferation and cytokine assays}

For proliferation studies, biopsy-derived cells were cultured on 24-well or six-well plates, at a density of $1.5-2 \times 10^{4}$ cells $\cdot \mathrm{cm}^{-2}$ in DMEM with $10 \%$ FCS, and rendered quiescent by $24 \mathrm{~h}$ serum deprivation. Cells were treated with thrombin $\left(0.3 \mathrm{U} \cdot \mathrm{mL}^{-1}\right)$, FGF-2 (300 pM) or FCS (5\% v/v) with Monomed A (1\% v/v) to provide progression factors essential for mitogen activity. In some experiments, fluticasone propionate (FP; 0.1 or $1 \mathrm{nM})$ and/ or salmeterol (10 or $30 \mathrm{nM}$ ) were added $30 \mathrm{~min}$ before thrombin. Briefly, cells were stimulated for $24 \mathrm{~h}$, before being pulsed with ${ }^{3} \mathrm{H}$-thymidine $\left(1 \mu \mathrm{Ci} \cdot \mathrm{ml}^{-1}\right)$ for $4 \mathrm{~h}$, or stimulated for $48 \mathrm{~h}$ before enumeration by haemocytometry. Cell viability (Trypan Blue exclusion) was $>98 \%$ in all experiments. IL- $1 \alpha\left(1 \mathrm{ng} \cdot \mathrm{mL}^{-1}\right)$ was used as the stimulus for cytokine production. Supernatants were assayed for GM-CSF and IL-8 by ELISA (Endogen, Rockford, IL, USA), and for prostaglandin (PG) $\mathrm{E}_{2}$ by radioimmunoassay [27]. Justification of concentrations used and details of proliferation and cytokine assays are provided in the supplementary material.

\section{Statistical analyses}

For nonparametric data (subject characteristics, total biopsy area, smooth muscle area and cyclin D1 data), comparisons were made using the Kruskal-Wallis test followed by Dunn's post hoc test for intergroup comparisons across groups with increasing asthma severity. For all other analyses, comparisons were made with all asthma subjects grouped together, as relatively few cell cultures were obtained from moderate and severe asthmatics. Mitogen responses were normally distributed, so one-tailed t-tests and unpaired t-tests were performed to test for responses within groups and differences between nonasthmatic and asthmatic groups, respectively. The effects of FP and/or salmeterol and of asthma status on thrombin responses were analysed using a fixed-effects model, two-way ANOVA. Cytokine levels were logtransformed to allow unpaired t-tests to be performed on normally distributed data. Differences were considered to be statistically significant when $\mathrm{p}<0.05$.

\section{RESULTS}

\section{Detection of proliferation in biopsies}

Although there was no difference in the total biopsy area across the nonasthmatic and stratified asthmatic groups, the 


\begin{tabular}{|c|c|c|c|c|c|c|}
\hline & \multicolumn{4}{|c|}{ Immunohistochemistry } & \multicolumn{2}{|c|}{ Cell culture } \\
\hline & Nonasthmatic & Mild asthma ${ }^{\#}$ & Moderate asthma ${ }^{\#}$ & Severe asthma ${ }^{\#}$ & Nonasthmatic & Asthmatic \\
\hline Subjects (M/F) $n$ & $34(21 / 13)$ & $38(24 / 14)$ & $5(4 / 1)$ & $14(6 / 8)$ & $22(15 / 7)$ & $25^{+}(16 / 9)$ \\
\hline Current smokers & 71 & $49^{\S}$ & 67 & $0^{f}$ & 82 & 52 \\
\hline \multicolumn{7}{|l|}{ Current treatment } \\
\hline$\beta_{2}$-adrenoceptor agonists & 0 & 74 & 100 & 100 & 0 & 76 \\
\hline Inhaled steroids & 0 & 37 & 80 & 100 & 0 & 40 \\
\hline Oral steroids & 0 & 0 & 0 & 64 & 0 & 0 \\
\hline
\end{tabular}

Data presented as median (interquartile range) or \%, unless otherwise stated. M: male; F: female; FEV1: forced expiratory volume in one second; \% pred: \% predicted. \#: classified using Global Initiative for Asthma guidelines; ": all asthmatics were combined for analysis since few biopsies from moderate or severe asthmatics were available for culture; ${ }^{+}: 20$ mild, four moderate and one severe asthmatic; ${ }^{\text {s. }}$ smoking status unknown in $3 \% ;{ }^{f}$ : smoking status unknown in $14 \%{ }^{* *}: p<0.01 ;{ }^{* * *}: p<0.001$ for Kruskal-Wallis test followed by Dunn's post hoc test.

proportion of smooth muscle in the biopsies increased with increasing asthma severity $(\mathrm{p}<0.05$; table 2$)$.

Immunostaining for cyclin D1, a marker of proliferation, revealed that the number of positive cells increased with asthma severity, with a 3.5-fold higher median value for severe asthmatics compared with nonasthmatics (fig. 1). Biopsies with the highest levels of immunostaining were obtained from four female patients with asthma of varying severity (two mild and two severe). The characteristics of these patients were generally unremarkable, although all were on current treatment with oral steroids.

Cyclin D1 immunoreactivity was not detected in the smooth muscle bundles, but was restricted to the epithelium and subepithelial connective tissue (fig. 1). Therefore, further studies were performed, in order to characterise the proliferative properties of mesenchymal cells derived from a subset of the biopsies.

\section{Comparison of resection and biopsy-derived mesenchymal cells in culture}

Preliminary comparisons were made between cultures of airway myofibroblasts and smooth muscle isolated from lung resection specimens, in order to establish phenotypic characteristics that could be used to identify the biopsy-derived mesenchymal cells. Cells from the same subject could be distinguished by fluorescence-activated cell sorter analysis, which showed that myofibroblasts tended to be larger than airway smooth muscle cells obtained from the same subject, with mean \pm SEM forward scatter values of $327 \pm 26$ and $369 \pm 26$, respectively $(n=3$; $\mathrm{p}=0.07$; paired t-test).

Cells from endobronchial biopsies were larger and more elongated than resection-derived airway smooth muscle (fig. 2), but were similar, both in appearance and in immunostaining for phentotypic markers, to myofibroblasts from lung resections (data not shown). Detailed comparisons between these biopsy-derived myofibroblasts and resection-derived airway smooth muscle cells are shown in figure 2 . Both cell types showed similar positive immunostaining for the contractile protein $\alpha$-SMA. However, for the collagen cross-linking enzyme proline-4-hydroxylase, immunostaining was intense and punctate for biopsy-derived cells but diffuse and light for airway smooth muscle cells. In addition, vimentin immunostaining appeared more marked for cells from endobronchial biopsies than airway smooth muscle. Labelling with the epithelial marker cytokeratin was not detected in any cultures. On the basis of these findings, the biopsy-derived

TABLE 2 Total area and smooth muscle area of biopsies from nonasthmatic and asthmatic subjects used for cyclin D1 immunohistochemistry

\begin{tabular}{lcccc} 
& Nonasthmatic & Mild asthma & Moderate asthma & Severe asthma \\
\hline Subjects $\mathbf{n}$ & 34 & 38 & 5 & 14 \\
Total biopsy area $\mathbf{~ m}^{2}$ & $0.22(0.17-0.34)$ & $0.28(0.15-0.36)$ & $0.33(0.16-0.33)$ & $0.26(0.17-0.50)$ \\
Smooth muscle area \% & $0.7(0-5.7)$ & $3.0(0-7.8)$ & $1.1(0-20.5)$ & $19.9(3.8-34.9)^{\star \star}$ \\
\hline
\end{tabular}

Data are presented as median (interquartile range), unless otherwise stated. **: $\mathrm{p}<0.01$ compared with nonasthmatic (Kruskal-Wallis test followed by Dunn's post hoc test). 

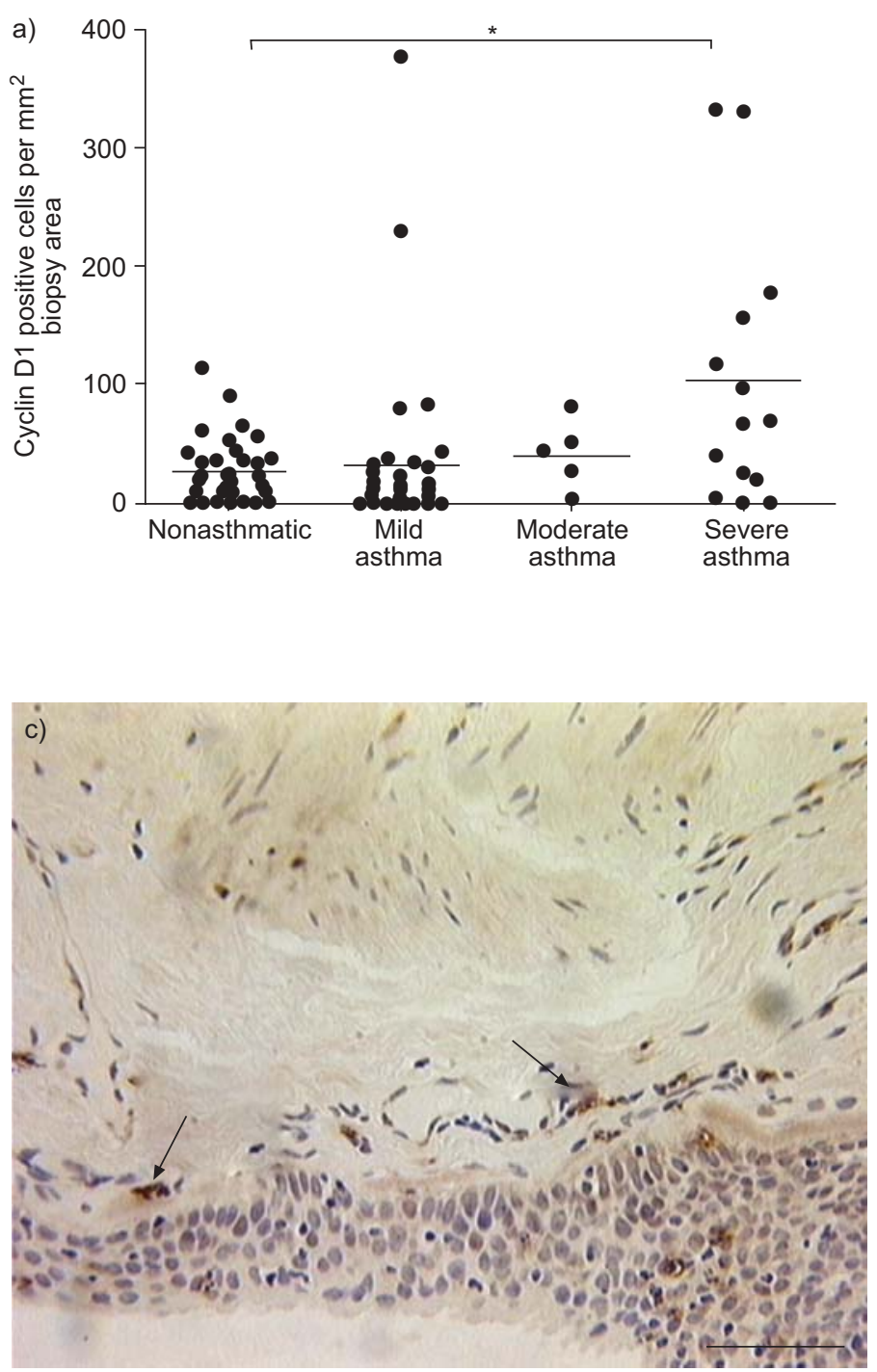
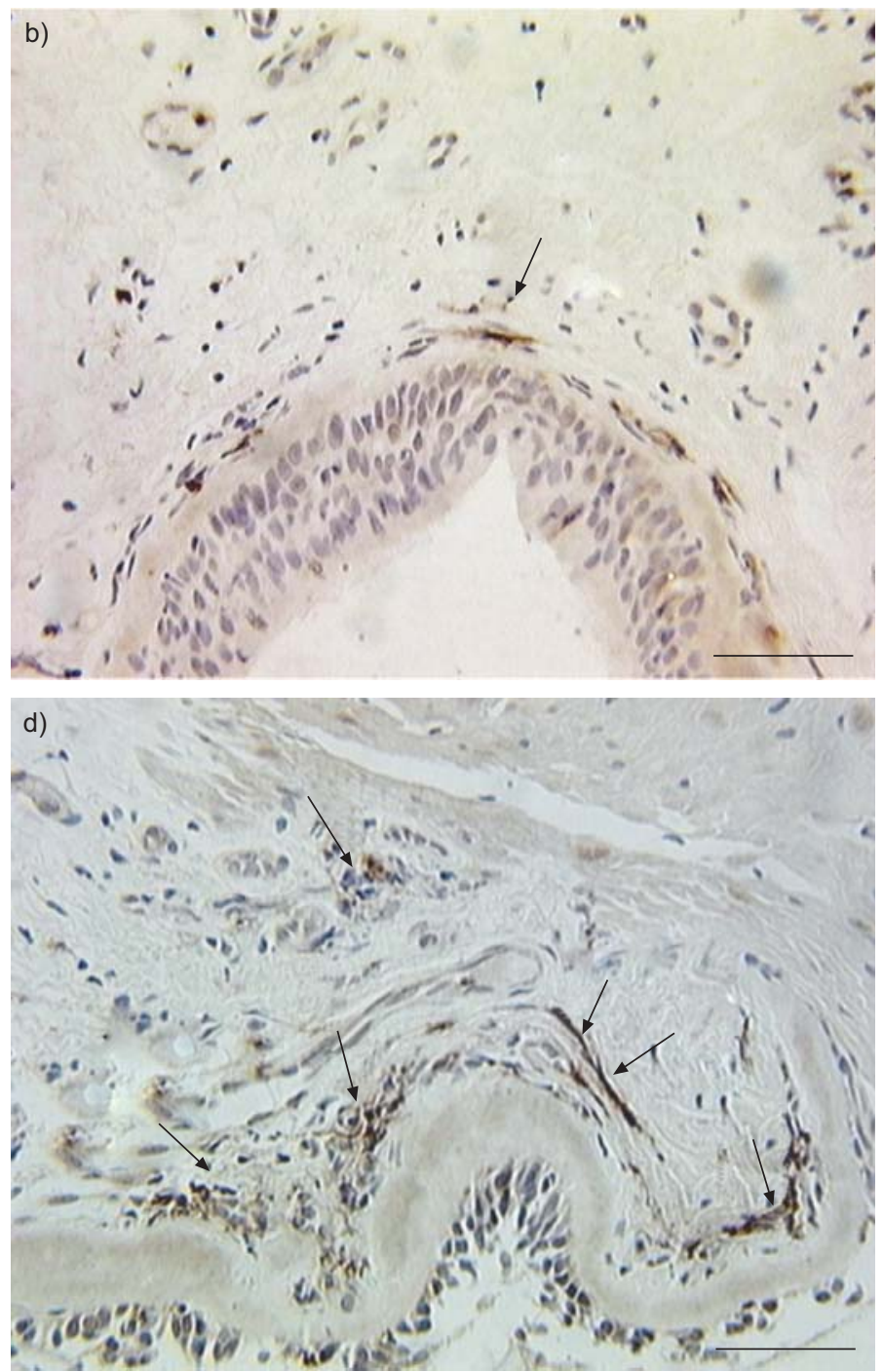

FIGURE 1. a) Quantitation of cyclin D1-positive cell numbers in biopsies from subjects with increasing asthma severity. Individual and median values from nonasthmatic $(n=34)$, mild asthmatic $(n=38)$, moderate asthmatic $(n=5)$ and severe asthmatic $(n=14)$ subjects are shown. Immunohistochemistry for cyclin $D 1$ in endobronchial biopsies from b) a nonasthmatic, c) a mild asthmatic and d) a severe asthmatic subject. Arrows indicate cyclin D1-positive cells. *: $p<0.05$, Kruskal-Wallis test. Scale bars $=50$ mm.

mesenchymal cells were identified as predominantly airway myofibroblasts [26].

\section{Biopsy-derived cell culture studies}

Subsequent experiments were performed on myofibroblast cultures obtained from additional biopsies from nonasthmatics and asthmatics. Cultures were established from 22 of the 34 nonasthmatics, 20 of the 38 mild asthmatics, four of the five moderate asthmatics but only one of the 14 severe asthmatics with matching immunohistochemical data (table 1). These variable proportions reflect the availability of biopsy material dedicated to cell culture, which was most limited in the severe asthmatics, rather than the success in establishing cultures ( $\sim 75 \%$ for both the nonasthmatic and asthmatic groups). Therefore, these cell culture studies were not statistically powered to examine the influence of asthma severity or other patient characteristics, such as smoking status, and results from all asthmatic cultures are presented and analysed together.

\section{Proliferation: ${ }^{3} \mathrm{H}$-thymidine incorporation and cell enumeration}

Under matched culture conditions, the mean \pm SEM time taken to establish confluent cultures from biopsies from nonasthmatics and all asthmatics was not significantly different between groups ( $48 \pm 4$ days, $n=22$, versus $45 \pm 3$ days, $n=25$, respectively; $\mathrm{p}>0.05$ ).

${ }^{3} \mathrm{H}$-Thymidine uptake was assessed in myofibroblasts from nonasthmatic and asthmatic subjects, plated at the same cell density. Although basal ${ }^{3} \mathrm{H}$-thymidine incorporation over $4 \mathrm{~h}$ appeared higher at passage five compared with all later passages, it was similar in both groups and did not change significantly with increasing passage number in either group (fig. 3).

The median (interquartile range) passage number at which the effects of FGF-2 (300 pM), thrombin $\left(0.3 \mathrm{U} \cdot \mathrm{mL}^{-1}\right)$ and FCS $(5 \%)$ were assessed did not differ for nonasthmatics and asthmatics (5.8 (5.1-6.6), $\mathrm{n}=18$, versus $6.6(5.3-7.6), \mathrm{n}=26$, respectively; 

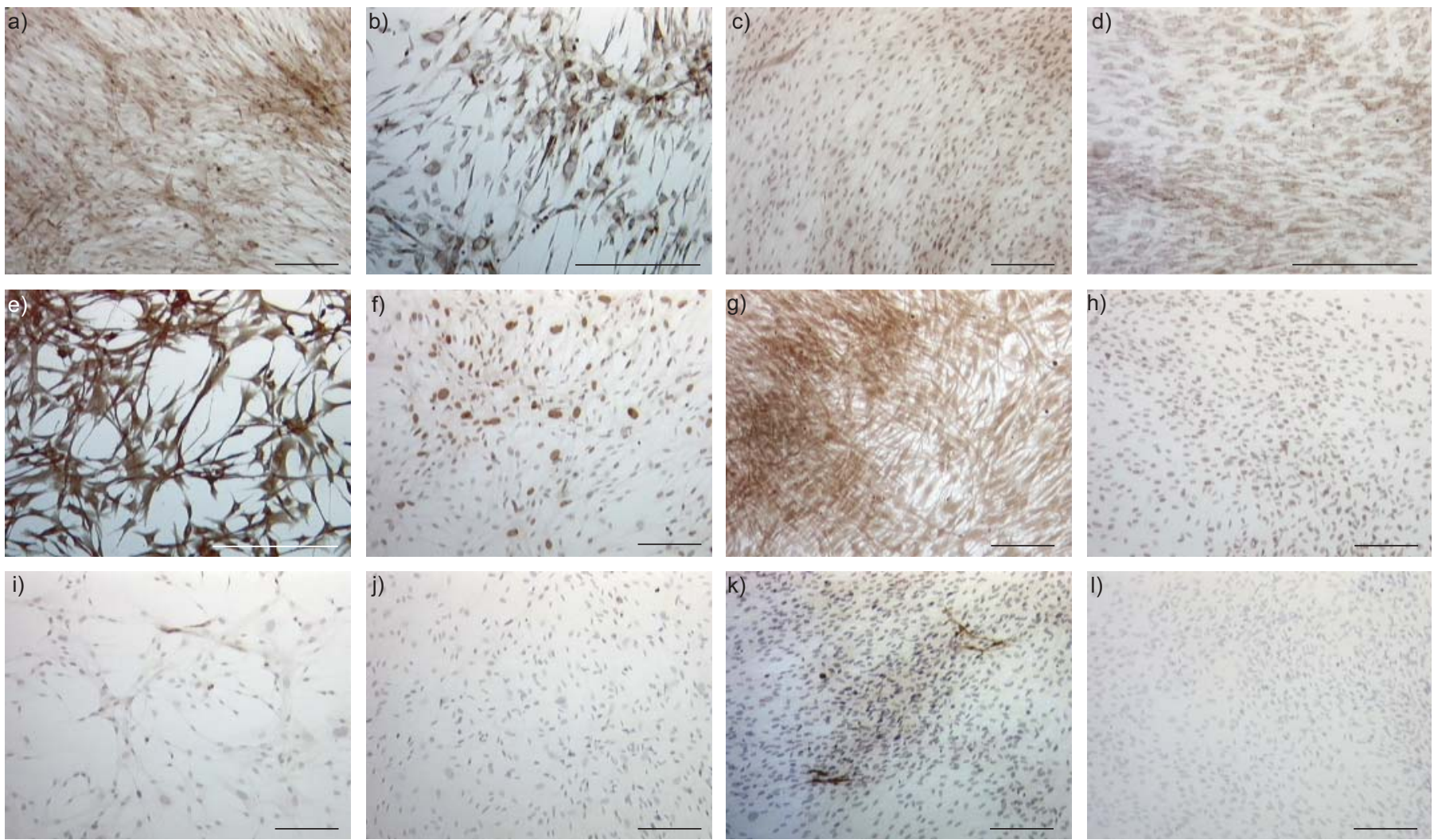

FIGURE 2. Comparative immunohistochemistry for human airway myofibroblast ( $a, b, e, f, i$ and j) and smooth muscle (c, $d, g, h, k$ and $l)$ cultures, derived from an endobronchial biopsy and a lung resection specimen, respectively. Immunostaining was performed for $\alpha$-smooth muscle actin (a and c), proline-4-hydroxylase clone 5B5 (b and d), vimentin (e and g), smooth muscle myosin ( $\mathrm{f}$ and $\mathrm{h}$ ) and pan cytokeratin ( $\mathrm{i}$ and $\mathrm{k}$ ). $\mathrm{j}$ and I) Immunoglobulin G1 as negative controls. The patterns shown are representative of three experiments. Scale bars $=100 \mu \mathrm{m}$.

$\mathrm{p}>0.05)$. Significant increases in ${ }^{3} \mathrm{H}$-thymidine uptake were found in response to these stimuli $(\mathrm{p}<0.05$ using one-sample t-test; table 3). However, there were no significant differences in ${ }^{3} \mathrm{H}$-thymidine uptake between the asthmatic and nonasthmatic groups, irrespective of the mitogen used.

Direct cell counts were obtained, in order to extend the findings with ${ }^{3} \mathrm{H}$-thymidine. In these experiments, the median (interquartile range) passage number at which proliferation was assessed using cell enumeration did not differ for nonasthmatics and asthmatics (6.8 (5.0-8.1), $\mathrm{n}=16$, versus 8.0 (5.5-8.3), $\mathrm{n}=21$, respectively; $\mathrm{p}>0.05)$. Basal proliferation was measured for cells plated at the same initial density then enumerated after incubation for $48 \mathrm{~h}$ in the presence of progression factors (insulin, transferrin and selenium) but in the absence of mitogen. Under these basal conditions, cell numbers increased but did not differ between nonasthmatics and asthmatics $\left(2.0 \pm 0.2 \times 10^{5}\right.$ cells $\cdot$ well $^{-1}, \mathrm{n}=20$, versus $1.7 \pm 0.2 \times 10^{5}$ cells well ${ }^{-1}, \mathrm{n}=21$, respectively; $\mathrm{p}>0.05$ ).

Incubation with FGF-2, thrombin or FCS induced increases in cell number over $48 \mathrm{~h}$, compared with unstimulated cells. The greatest proliferative responses to both FGF-2 and FCS were measured in myofibroblasts from the same two nonasthmatic patients. Within the asthmatic group, the greatest increase in cell number, with all the mitogens tested, was measured in a mild asthmatic patient who was not receiving oral steroids. This patient did not have elevated cyclin D1 immunostaining detected in the biopsy specimen from which the cells were derived. The characteristics of these subjects were otherwise unremarkable. However, cells from asthmatics had a reduced proliferative response to both thrombin and FGF-2, compared with cells from nonasthmatics $(p<0.05$; fig. 4$)$. This was not associated with cytolytic cell death or apoptosis, as Trypan Blue exclusion was $>98 \%$ with no morphological changes observed. FCS-stimulated proliferation was much more variable between subjects and there was no significant difference between patient groups.

\section{Effects of FP and salmeterol on proliferation}

The effects on proliferation of the currently used asthma treatments, FP and salmeterol, were assessed. FP (1 nM) had no effect on basal proliferation in cells from either nonasthmatic $(114 \pm 11 \%$ unstimulated cell number, $n=9 ; p>0.05)$, or asthmatic subjects $(104 \pm 9 \%, n=7 ; p>0.05)$. The degree of inhibition of the thrombin response with either 0.1 or $10 \mathrm{nM} \mathrm{FP}$ was similar in each group (fig. 5). In contrast, salmeterol appeared to inhibit thrombin-induced proliferation with greater effectiveness in cells from asthmatics, and the effect of salmeterol was significant only at $30 \mathrm{nM}$. Assessment of synergy in the effects of FP and salmeterol on the thrombininduced proliferation was precluded by the complete inhibitory effect of FP at $0.1 \mathrm{nM}$. However, the complete inhibition by FP was also observed in the presence of salmeterol in both groups (fig. 5). 


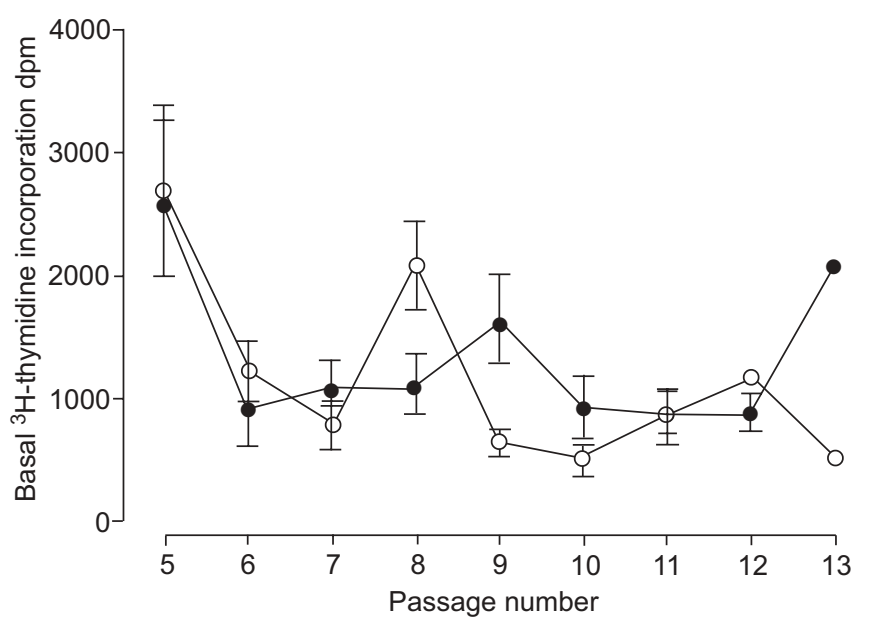

FIGURE 3. Effect of passage number on basal ${ }^{3} \mathrm{H}$-thymidine uptake in myofibroblasts from nonasthmatic $(\bigcirc)$ and asthmatic $(\mathbf{O})$ subjects. Results are presented as the mean \pm SEM ${ }^{3} \mathrm{H}$-thymidine uptake over a 4-h incubation period for cells plated at the same density. For nonasthmatics and asthmatics, there were $\leqslant 19$ and $\leqslant 25$ cultures at each passage, respectively; $p>0.05$.

\section{Release of GM-CSF, IL-8 and PGE}

Basal mean (interquartile range) GM-CSF supernatant levels were $144(108-153) \mathrm{pg} \cdot \mathrm{mL}^{-1}(\mathrm{n}=12)$ and $150(94-177) \mathrm{pg} \cdot \mathrm{mL}^{-1}$ $(n=14)$ in the nonasthmatic and asthmatic groups, respectively $(\mathrm{p}>0.05)$. Cell supernatant levels of IL-8 and $\mathrm{PGE}_{2}$, in the absence of inflammogen, were below the level of detection in each group.

GM-CSF, IL- 8 and PGE 2 levels increased in response to IL- $1 \alpha$. However, in marked contrast to reduced proliferation in the cells from asthmatics, IL- $1 \alpha$-dependent cytokine levels were increased in this group compared with nonasthmatics. IL- $1 \alpha$ induced a 10-fold increase in GM-CSF supernatant levels from asthmatic cells, and only a three-fold increase in cells from nonasthmatics (fig. 6). There was no significant difference in cell number in either nonasthmatic or asthmatic cells in the presence of IL- $1 \alpha$ (data not shown). Increases were also noted with IL- $1 \alpha$-dependent IL- 8 production from asthmatics compared with the nonasthmatic group (fig. 6). This difference was modest compared with the difference for GM-CSF. Cell supernatants from a single nonasthmatic subject had notably elevated GM-CSF levels, but not IL-8 levels. The same two asthmatic patients, one mild and one moderate, showed the highest levels of both GM-CSF and IL-8 (fig. 6). Asthma status did not have a detectable effect on IL- $1 \alpha$-stimulated $\mathrm{PGE}_{2}$ levels (data not shown).

\section{DISCUSSION}

The present study compared biopsies obtained from patients who had a range of asthma severity and treatment to those derived from nonasthmatic subjects, with the primary aim being to explore differences in proliferation in the airway wall in situ. Additionally, the proliferative and inflammatory capacities of myofibroblasts derived from these biopsies were assessed in vitro. This is one of the largest biopsy studies undertaken in subjects recruited from a longitudinal asthma and control cohort, since the majority of subjects (81 out of 92 studied) were from the MESCA cohort, in which data has been

\begin{tabular}{|c|c|c|c|c|c|}
\hline \multirow{3}{*}{$\begin{array}{l}\text { TABLE } 3 \\
\text { Stimulus }\end{array}$} & \multicolumn{5}{|c|}{$\begin{array}{l}\text { Effects of various stimuli on }{ }^{3} \mathrm{H} \text {-thymidine uptake } \\
\text { in myofibroblasts from nonasthmatic and } \\
\text { asthmatic subjects }\end{array}$} \\
\hline & \multicolumn{2}{|c|}{ Nonasthmatic } & \multicolumn{2}{|c|}{ Asthmatic } & \multirow[t]{2}{*}{$p$-value } \\
\hline & Uptake ${ }^{\#}$ & Cultures & Uptake $\#$ & Cultures & \\
\hline $\begin{array}{l}\text { Thrombin } \\
0.3 \mathrm{U} \cdot \mathrm{mL}^{-1}\end{array}$ & $155 \pm 9$ & 20 & $182 \pm 12$ & 25 & 0.08 \\
\hline FGF-2 300 pM & $147 \pm 14$ & 17 & $177 \pm 20$ & 21 & 0.27 \\
\hline FCS $5 \% \mathrm{v} / \mathrm{v}$ & $211 \pm 22$ & 14 & $183 \pm 15$ & 18 & 0.27 \\
\hline \multicolumn{6}{|c|}{$\begin{array}{l}\text { Data are presented as mean } \pm \text { SEM or } n \text {, unless otherwise stated. }{ }^{3} \mathrm{H} \text {-Thymidine } \\
\text { uptake was measured over a } 4 \text { - } \mathrm{h} \text { incubation period, } 24-28 \mathrm{~h} \text { after the addition } \\
\text { of stimulus. FGF: fibroblast growth factor; FCS: foetal calf serum; v: volume. } \\
\# \text { : percentage of uptake in unstimulated cells }(2,023 \pm 634 \mathrm{dpm}, \mathrm{n}=18 \text {, and } \\
1,721 \pm 451 \mathrm{dpm}, \mathrm{n}=26 \text {, for nonasthmatic and asthmatic, respectively; } \\
\mathrm{p}>0.05) \text {. }\end{array}$} \\
\hline
\end{tabular}

collected from participants every 7 yrs since they were aged 7 yrs $[19,20]$.

In biopsies, clear evidence was obtained for an increase in the percentage area occupied by the smooth muscle bundle with increasing asthma severity. This finding agrees with those from several groups of investigators [28-30]. Cyclin D1 was used as a marker of in situ proliferation, since it is elevated in cultured airway smooth muscle cells upon mitogen stimulation and is essential for proliferation of cultured fibroblasts and muscle cells [31, 32]. In keeping with previous studies assessing proliferation with either Ki67 or proliferating cell nuclear antigen expression [29], cyclin D1 staining of muscle cells was rarely detected and no differences were observed with asthma status. However, cyclin D1 immunostaining provided clear evidence of hyperproliferation of cells in other airway wall compartments contiguous with muscle bundles in biopsies from asthmatic subjects. This finding directed further investigations of the function of biopsy-derived cells in vitro.

There are a number of possible explanations for the absence of detectable proliferation specifically within smooth muscle bundles in situ. A short-lived period of muscle proliferation early in the course of the disease may have established asthma severity, such that ongoing proliferation of these cells is present only at very low frequencies in chronic asthma [33], or the smooth muscle cells may have reached senescence at the time of biopsy. However, the in vitro observations that cultured airway smooth muscle cells isolated from asthmatic biopsy patients are responsive to mitogen stimulation and are hyperproliferative in culture [5] argue against these asthmatic cells being senescent. Alternative additional mechanisms have been proposed for the increased amount of smooth muscle in the asthmatic airway that may not be detected using cell proliferation markers [34]. These include a decreased rate of muscle apoptosis [35] or migration and differentiation of circulating fibrocytes [36]. Alternatively, mesenchymal cells may undergo proliferation in the subepithelial region outside mature muscle bundles in response to micro-environment changes within the airway wall [37]. This proposed mechanism 

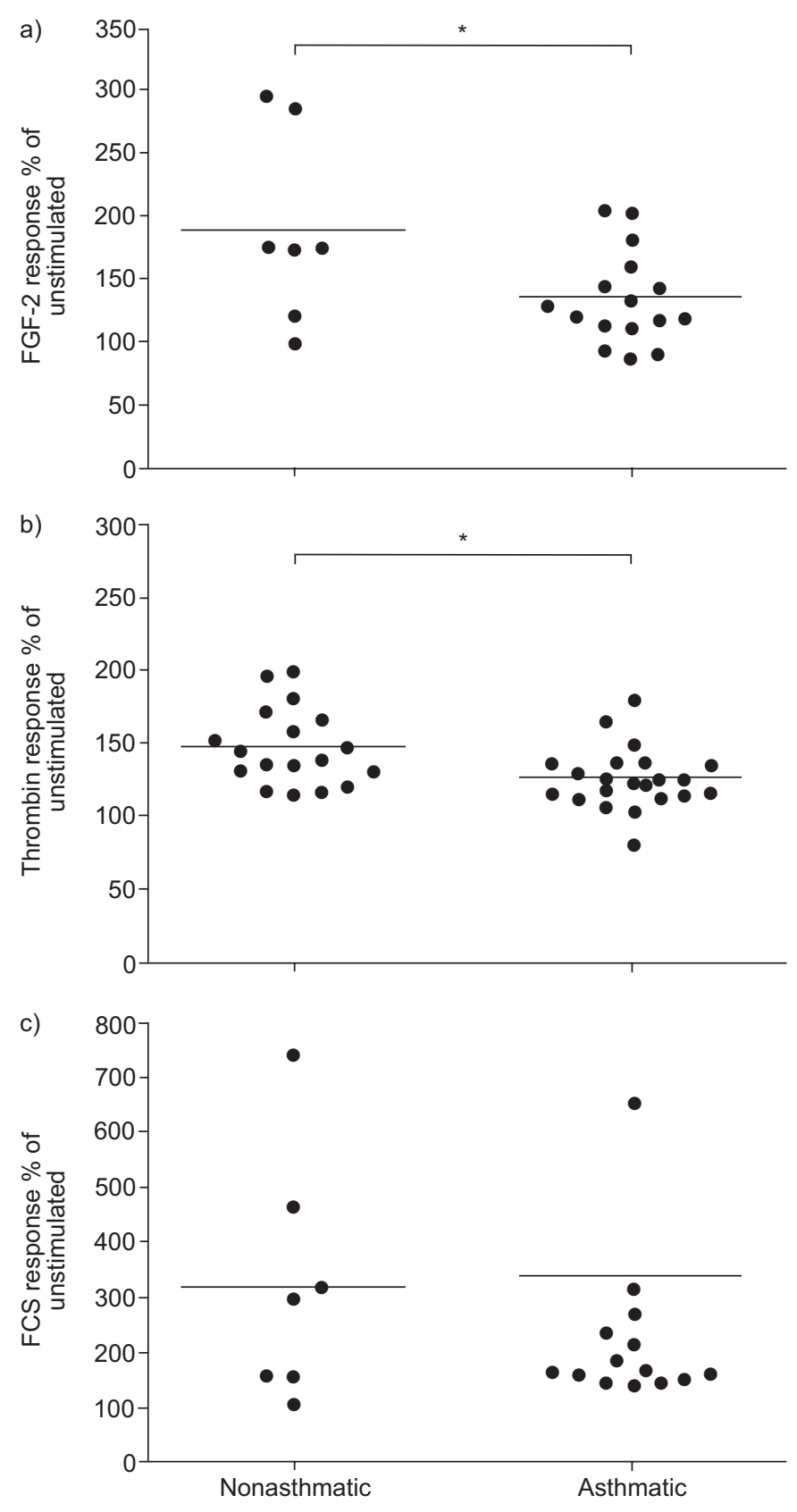

FIGURE 4. Effects of a) fibroblast growth factor (FGF)-2 (300 pM), b) thrombin $\left(0.3 \mathrm{U} \cdot \mathrm{mL}^{-1}\right)$ and c) foetal calf serum (FCS; $5 \%$ volume $\left.(\mathrm{v}) / \mathrm{v}\right)$ on proliferation of myofibroblasts from nonasthmatic and asthmatic subjects. Confluent cells were serum-deprived for $24 \mathrm{~h}$ then stimulated with mitogen for $48 \mathrm{~h}$ in the presence of essential progression factors. Cell numbers were determined by haemocytometry. Individual data points represent the average response from between one and six replicates within a given culture, expressed as a percentage of the unstimulated cell number. The mean responses are also shown. Numbers of cultures: a) seven nonasthmatic, 16 asthmatic; b) 18 nonasthmatic, 21 asthmatic; c) seven nonasthmatic, 14 asthmatic. *: $p<0.05$, unpaired t-test.

is speculative and requires the cells subsequently to differentiate to adopt a smooth muscle phenotype and to migrate in order to contribute to the increase in smooth muscle volume.

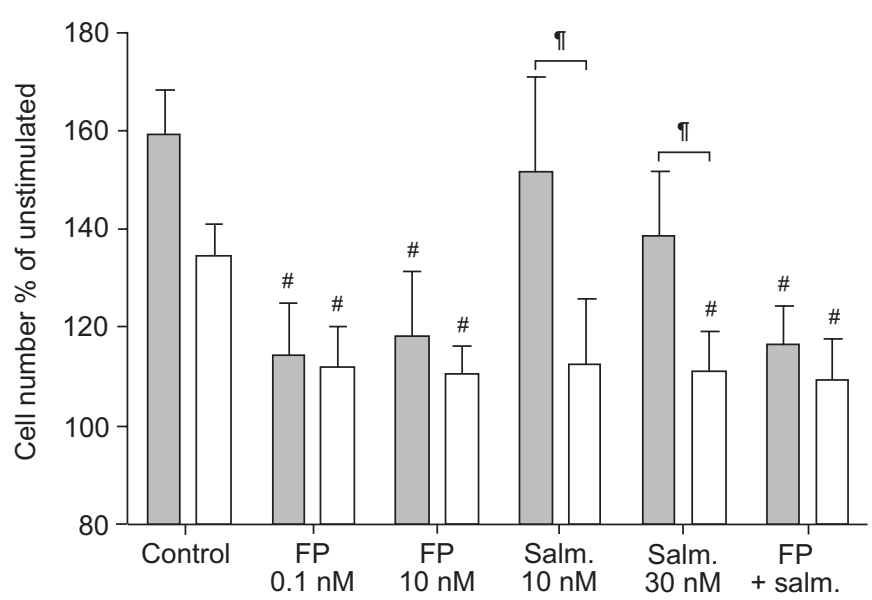

FIGURE 5. Effect of fluticasone propionate (FP) and salmeterol (salm.) on thrombin $\left(0.3 \mathrm{U} \cdot \mathrm{mL}^{-1}\right)$-induced proliferation of myofibroblasts from nonasthmatic $(\square)$ and asthmatic $(\square)$ subjects. FP (0.1 or $1 \mathrm{nM}$ ), salm. (10 or $30 \mathrm{nM}$ ) or both (FP $0.1 \mathrm{nM}$, salm. $30 \mathrm{nM}$ ) were added to serum-deprived cells 30 min prior to thrombin addition. The control cells received thrombin alone. Cell numbers were determined by haemocytometry after $48 \mathrm{~h}$. Data are presented as mean \pm SEM of the response, expressed as a percentage of the unstimulated cell number (in the absence of thrombin). One to four replicates were performed for each culture (nine nonasthmatic, seven asthmatic). ${ }^{*}: p<0.05$ for comparison with control within asthma status group; ": $p<0.05$ for comparison with nonasthmatic under same conditions.

Given this context, and evidence of increased cellular cyclin D1 immunostaining with increasing asthma severity within the biopsies from the MESCA cohort, it was of particular interest also to examine cells derived from this collagen-rich subepithelial region. It was therefore necessary to phenotype these cells and explore their responsiveness to mitogens and inflammatory mediators. Such studies have the potential to elucidate inherent differences in the characteristics with asthmatic status, or to provide evidence for changes in function that may occur selectively in the complex milieu of the asthmatic airway wall.

Comparison of morphological and immunohistochemical characteristics revealed that the biopsy-derived cells were similar to resection-derived myofibroblasts but could be distinguished from airway smooth muscle cells. Although neither the presence of smooth muscle cells in the biopsy cultures nor the changing of the proportion of these cells with asthma severity can be completely excluded, the predominant phenotype of the cells characterised in these cultures was myofibroblast-like [26].

Assessment of proliferative markers showed no evidence of increased basal proliferation of myofibroblasts cultured from the asthmatic biopsies, despite increased expression of cyclin D1 in subepithelial connective tissue areas of the histological sections. A possible explanation for this discrepancy is that detection of asthma-related changes in proliferation may be less apparent when cells are maintained in culture isolated from the asthmatic micro-environment of the intact airway wall (and the associated cell interactions, mitogens, inflammatory milieu and drug treatments). 

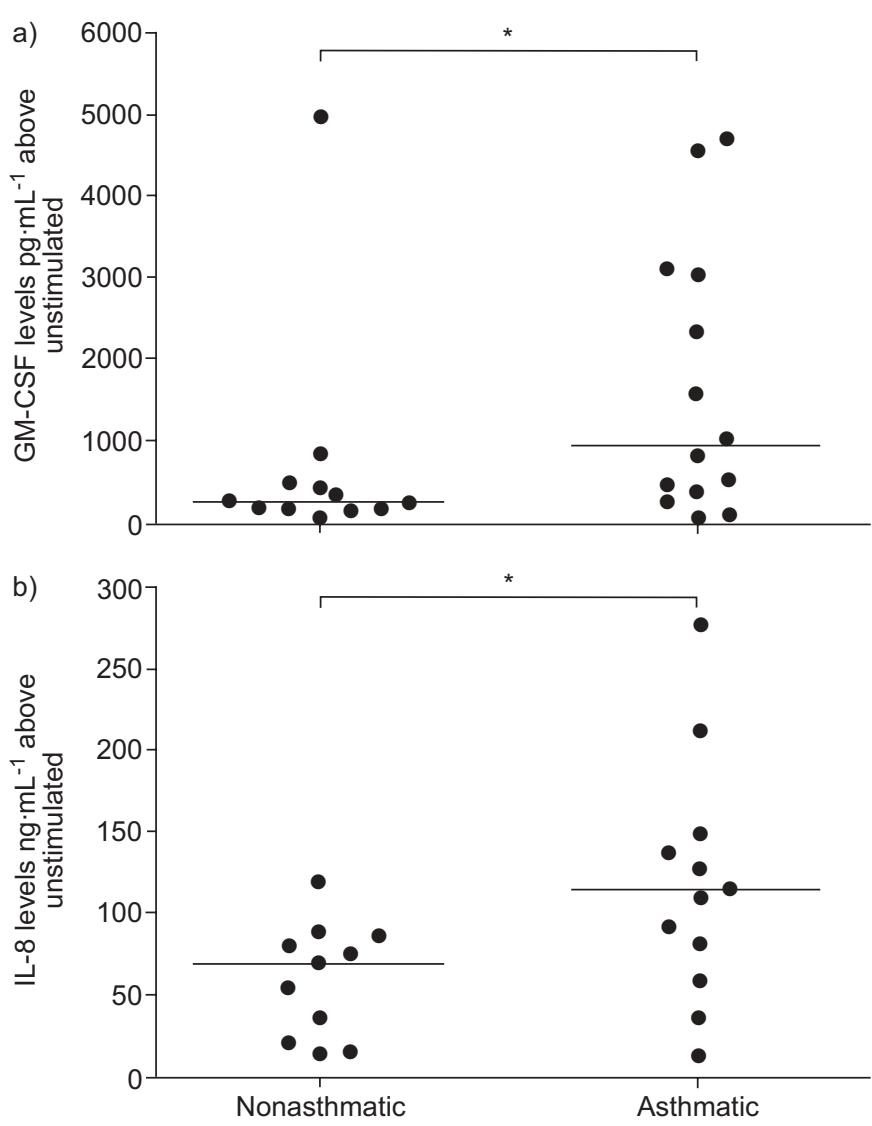

FIGURE 6. Effect of interleukin (IL)-1 $\alpha\left(1 \mathrm{ng} \cdot \mathrm{mL}^{-1}\right)$ on supernatant levels of inflammatory mediators for myofibroblasts from nonasthmatic and asthmatic subjects. Confluent cells were serum-deprived for $24 \mathrm{~h}$ then incubated with IL-1 $\alpha$ for $48 \mathrm{~h}$. Supernatant levels of granulocyte-macrophage colony-stimulating factor (GM-CSF) and IL-8 were measured using ELISA. Individual data points represent the average increase in response to IL-1 $\alpha$ above unstimulated levels from between one and 11 replicates within a given culture. The median responses are also shown. Numbers of cultures: a) 12 nonasthmatic, 14 asthmatic; b) 11 nonasthmatic, 12 asthmatic. ${ }^{*}$ : $p<0.05$, unpaired t-test on log-transformed data.

When cultured in the presence of mitogens, unequivocal evidence in myofibroblasts from asthmatics of a reduced proliferative response to thrombin and FGF-2 was obtained. Critically, this is in contradistinction to the mitogen-induced hyperproliferation described in airway smooth muscle cultured from asthmatics [5]. Phenotypic differences in mitogenic signalling between mesenchymal cell types, with different cell populations derived from different locations within the airway, may contribute to varying proliferative responses under culture conditions. Elsewhere, characteristics of proximal and distal fibroblasts, including mitogenic responses, have previously been shown to vary significantly [38].

When the effects of current asthma treatments on the myofibroblast mitogenic response were assessed, the $\beta_{2}$-adrenoceptor agonist salmeterol did not inhibit proliferation in cells from nonasthmatics, in agreement with a recent report [39]. However, in the current study, a small attenuation of the thrombinmediated response was evident in asthmatic-derived myofibroblasts but only at the highest concentration examined. This apparently increased sensitivity of asthmatic myofibroblasts to salmeterol may reflect their relatively reduced proliferative response to thrombin compared with myofibroblasts from nonasthmatics. In contrast, the glucocorticoid FP was found to exert similar antiproliferative effects in myofibroblasts from both nonasthmatic and asthmatic patients. These findings using cell enumeration were in contrast to previous studies where dexamethasone was reported to increase ${ }^{3} \mathrm{H}$-thymidine incorporation in primary asthmatic but not normal bronchial fibroblasts [7], an observation confirmed in fibroblasts from mild but not severe asthmatics [9].

Alterations in regulation of release of cytokines and mediators from myofibroblasts could either perpetuate or minimise the inflammatory process and remodelling associated with asthma. Although there was no difference in basal secretion, IL- $1 \alpha$-stimulated levels of inflammatory cytokines were greater with asthma, consistent with previous reports in airway smooth muscle $[17,18]$. The production of GM-CSF may be regulated by IL-1-induced $\mathrm{PGE}_{2}$ synthesis and activation of $\mathrm{PGE}_{2}$ receptors, subtype EP2 [40, 41]. Although $\mathrm{PGE}_{2}$ production was shown to be maintained in the asthmatic myofibroblasts, downregulation of EP2 receptors may contribute to impairment of the negative feedback loop regulating GM-CSF release, as has been demonstrated in fibroblasts following fibrotic lung injury [42]. The measured cell supernatant concentrations of GM-CSF were up to two orders of magnitude higher than those measured in BAL following segmental lung allergen challenge [43], so that, even allowing for dilution in the BAL, this increased GM-CSF production could be functionally significant. Future studies could evaluate receptor and cytokine expression and downstream signalling pathways for differential regulation of cytokine production by these biopsy-derived mesenchymal cells in asthma.

In this community-based MESCA cohort, the recruitment process precluded controlling for potential confounding factors, such as atopy, smoking status or asthma therapy, in either the biopsy or the cell culture study. Furthermore, availability of biopsies dedicated to the in vitro study varied according to subject numbers within each group and the suitability of these biopsy samples for cell culture. Post hoc stratification within the in vitro study would have led to increasingly smaller subsets of data and a reduction in the statistical power.

The effects of prior drug treatment on cell function must also be considered, since the majority of asthmatic subjects were using both $\beta_{2}$-adrenoceptor agonists and inhaled glucocorticoids. However, a direct effect persisting after cells had been isolated and maintained in culture over many weeks is unlikely, although it is possible that a selection pressure exerted by anti-asthma drugs in the pro-mitogenic environment of the asthmatic airway may persist in cultured populations.

Another potential influence on the outcomes of the present study is smoking status. Acute exposure of fibroblasts to cigarette smoke extract has been shown to stimulate GM-CSF and IL- 8 production [44, 45], and smoking may alter the therapeutic response to glucocorticoids in asthma [46]. The possibility that a distinct asthma phenotype is associated with 
smoking could not be tested in the current study. Despite the size of the cohort, numbers within each subject group were insufficient to stratify prospectively by smoking status. Nevertheless, striking differences were observed in proliferative indices and in the production of specific cytokines between the nonasthmatic and asthmatic subject groups. Given that the proportion of smokers did not vary between groups in either biopsy or culture studies, these current findings are of particular interest when considered in relation to the wider literature in which smokers have been excluded.

In conclusion, immunostaining for cyclin D1 in airway biopsy specimens from asthmatics provided evidence of persistent increased proliferation in the epithelium and subepithelial connective tissue. Proliferation was not apparent within airway smooth muscle bundles, despite established muscle accumulation in asthma. Biopsy-derived cells were characterised as myofibroblasts, with cells from asthmatics showing a hypoproliferative response to mitogens known to be elevated in the asthmatic airway and sensitivity to inhibitory effects of glucocorticoids and $\beta$-agonists. Increased cytokine production, particularly of granulocyte-macrophage colony-stimulating factor, by cells derived from asthmatics supports their potential contribution to airway inflammation. This study offers insights into the contribution of myofibroblasts to inflammation, airway remodelling and airway hyperresponsiveness associated with asthma.

\section{REFERENCES}

1 James AL, Paré PD, Hogg JC. The mechanics of airway narrowing in asthma. Am Rev Respir Dis 1989; 139: 242-246.

2 Woolcock AJ, Anderson SD, Peat JK, et al. Characteristics of bronchial hyperresponsiveness in chronic obstructive pulmonary disease and in asthma. Am Rev Respir Dis 1991; 143: 1438-1443.

3 Panettieri RA Jr. Effects of corticosteroids on structural cells in asthma and chronic obstructive pulmonary disease. Proc Am Thorac Soc 2004; 1: 231-234.

4 Hirst SJ, Martin JG, Bonacci JV, et al. Proliferative aspects of airway smooth muscle. J Allergy Clin Immunol 2004; 114 : Suppl. 2, S2-S17.

5 Johnson PR, Roth M, Tamm M, et al. Airway smooth muscle cell proliferation is increased in asthma. Am J Respir Crit Care Med 2001; 164: 474-477.

6 Roth M, Johnson PR, Borger $\mathrm{P}$, et al. Dysfunctional interaction of $\mathrm{C} / \mathrm{EBP} \alpha$ and the glucocorticoid receptor in asthmatic bronchial smooth-muscle cells. N Engl J Med 2004; 351: 560-574.

7 Dubé J, Chakir J, Laviolette $\mathrm{M}$, et al. In vitro procollagen synthesis and proliferative phenotype of bronchial fibroblasts from normal and asthmatic subjects. Lab Invest 1998; 78: 297-307.

8 Dubé J, Chakir J, Dubé C, Grimard Y, Laviolette M, Boulet LP. Synergistic action of endothelin (ET)-1 on the activation of bronchial fibroblast isolated from normal and asthmatic subjects. Int J Exp Pathol 2000; 81: 429-437.

9 Kraft M, Lewis C, Pham D, Chu HW. IL-4, IL-13, and dexamethasone augment fibroblast proliferation in asthma. J Allergy Clin Immunol 2001; 107: 602-606.
10 Tomlinson PR, Wilson JW, Stewart AG. Inhibition by salbutamol of the proliferation of human airway smooth muscle cells grown in culture. Br J Pharmacol 1994; 111: 641-647.

11 Panettieri RA Jr, Hall IP, Maki CS, Murray RK. $\alpha$-Thrombin increases cytosolic calcium and induces human airway smooth muscle cell proliferation. Am J Respir Cell Mol Biol 1995; 13: 205-216.

12 Silvestri M, Fregonese L, Sabatini F, Dasic G, Rossi GA. Fluticasone and salmeterol downregulate in vitro, fibroblast proliferation and ICAM-1 or H-CAM expression. Eur Respir J 2001; 18: 139-145.

13 Zhang S, Mohammed Q, Burbidge A, Morland CM, Roche WR. Cell cultures from bronchial subepithelial myofibroblasts enhance eosinophil survival in vitro. Eur Respir J 1996; 9: 1839-1846.

14 Tran T, Fernandes DJ, Schuliga M, Harris T, Landells L, Stewart AG. Stimulus-dependent glucocorticoid-resistance of GM-CSF production in human cultured airway smooth muscle. Br J Pharmacol 2005; 145: 123-131.

15 Spoelstra FM, Postma DS, Hovenga H, Noordhoek JA, Kauffman HF. Additive anti-inflammatory effect of formoterol and budesonide on human lung fibroblasts. Thorax 2002; 57: 237-241.

16 Chen G, Grotendorst G, Eichholtz T, Khalil N. GM-CSF increases airway smooth muscle cell connective tissue expression by inducing TGF- $\beta$ receptors. Am J Physiol Lung Cell Mol Physiol 2003; 284: L548-L556.

17 Chan V, Burgess JK, Ratoff JC, et al. Extracellular matrix regulates enhanced eotaxin expression in asthmatic airway smooth muscle cells. Am J Respir Crit Care Med 2006; 174: 379-385.

18 Black JL, Burgess JK, Johnson PR. Airway smooth muscle its relationship to the extracellular matrix. Respir Physiol Neurobiol 2003; 137: 339-346.

19 Oswald H, Phelan PD, Lanigan A, Hibbert M, Bowes G, Olinsky A. Outcome of childhood asthma in mid-adult life. BMJ 1994; 309: 95-96.

20 Horak E, Lanigan A, Roberts M, et al. Longitudinal study of childhood wheezy bronchitis and asthma: outcome at age 42. BMJ 2003; 326: 422-423.

21 Bamford TL, Rolland J, Wilson JW, et al. Cellular localisation of cyclin D1 in non-asthmatic controls and steroid resistant asthmatics. Am J Respir Crit Care Med 2002; 165: A540.

22 Mast AE, Bamford TL, Wilson JW, et al. Smoooth muscle area is increased in bronchial biopsies from steroid resistant asthma. Am J Respir Crit Care Med 2003; 167: A33.

23 NHLBI/WHO Workshop Report: Global Strategy for Asthma Management and Prevention. Global Initiative for Asthma, 2002. National Institutes of Health Publication No. 02-3659, pp. 67-79. Available from www.ginasthma. org Date last updated: 2002.

24 Wilson JW, Li X. The measurement of reticular basement membrane and submucosal collagen in the asthmatic airway. Clin Exp Allergy 1997; 27: 363-371.

25 Panettieri RA, Murray RK, DePalo LR, Yadvish PA, Kotlikoff MI. A human airway smooth muscle cell line that retains physiological responsiveness. Am J Physiol 1989; 256: C329-C335. 
26 Serini G, Gabbiani G. Mechanisms of myofibroblast activity and phenotypic modulation. Exp Cell Res 1999; 250: 273-283.

27 Tran T, Stewart AG. Protease-activated receptor (PAR)independent growth and pro-inflammatory actions of thrombin on human cultured airway smooth muscle. $\mathrm{Br} \mathrm{J}$ Pharmacol 2003; 138: 865-875.

28 Ebina M, Takahashi T, Chiba T, Motomiya M. Cellular hypertrophy and hyperplasia of airway smooth muscles underlying bronchial asthma. A 3-D morphometric study. Am Rev Respir Dis 1993; 148: 720-726.

29 Benayoun L, Druilhe A, Dombret MC, Aubier M, Pretolani M. Airway structural alterations selectively associated with severe asthma. Am J Respir Crit Care Med 2003; 167: 1360-1368.

30 Woodruff PG, Dolganov GM, Ferrando RE, et al. Hyperplasia of smooth muscle in mild to moderate asthma without changes in cell size or gene expression. Am J Respir Crit Care Med 2004; 169: 1001-1006.

31 Fernandes D, Guida E, Koutsoubos V, et al. Glucocorticoids inhibit proliferation, cyclin D1 expression, and retinoblastoma protein phosphorylation, but not activity of the extracellular-regulated kinases in human cultured airway smooth muscle. Am J Respir Cell Mol Biol 1999; 21: 77-88.

32 Xiong W, Pestell RG, Watanabe G, Li J, Rosner MR, Hershenson MB. Cyclin D1 is required for S phase traversal in bovine tracheal myocytes. Am J Physiol 1997; 272: L1205-L1210.

33 James AL, Carroll M, Dromey J, et al. In situ proliferation of inflammatory cells and smooth muscle cells in patients with and without asthma. Respirology 2002; 7: Suppl. 1, A11.

34 Stewart AG. Emigration and immigration of mesenchymal cells: a multicultural airway wall. Eur Respir J 2004; 24: 515-517.

35 Ramos-Barbón D, Ludwig MS, Martin JG. Airway remodeling: lessons from animal models. Clin Rev Allergy Immunol 2004; 27: 3-21.

36 Schmidt M, Sun G, Stacey MA, Mori L, Mattoli S. Identification of circulating fibrocytes as precursors of bronchial myofibroblasts in asthma. J Immunol 2003; 171: 380-389.
37 Gizycki MJ, Adelroth E, Rogers AV, O’Byrne PM, Jeffery PK. Myofibroblast involvement in the allergen-induced late response in mild atopic asthma. Am J Respir Cell Mol Biol 1997; 16: 664-673.

38 Kotaru C, Schoonover KJ, Trudeau JB, et al. Regional fibroblast heterogeneity in the lung: implications for remodeling. Am J Respir Crit Care Med 2006; 173: 1208-1215.

39 Descalzi D, Folli C, Nicolini G, et al. Anti-proliferative and anti-remodelling effect of beclomethasone dipropionate, formoterol and salbutamol alone or in combination in primary human bronchial fibroblasts. Allergy 2008; 63: 432-437.

40 Patil RR, Borch RF. Granulocyte-macrophage colonystimulating factor expression by human fibroblasts is both upregulated and subsequently downregulated by interleukin-1. Blood 1995; 85: 80-86.

41 Clarke DL, Belvisi MG, Catley MC, Yacoub MH, Newton $\mathrm{R}$, Giembycz MA. Identification in human airways smooth muscle cells of the prostanoid receptor and signalling pathway through which $\mathrm{PGE}_{2}$ inhibits the release of GMCSF. Br J Pharmacol 2004; 141: 1141-1150.

42 Moore BB, Ballinger MN, White ES, et al. Bleomycin-induced E prostanoid receptor changes alter fibroblast responses to prostaglandin $\mathrm{E}_{2}$. J Immunol 2005; 174: 5644-5649.

43 Kato M, Liu MC, Stealey BA, et al. Production of granulocytemacrophage colony-stimulating factor in human airways during allergen-induced late-phase reactions in atopic subjects. Lymphokine Cytokine Res 1992; 11: 287-292.

44 Sato E, Koyama S, Takamizawa A, et al. Smoke extract stimulates lung fibroblasts to release neutrophil and monocyte chemotactic activities. Am J Physiol 1999; 277: L1149-L1157.

45 Martey CA, Pollock SJ, Turner CK, et al. Cigarette smoke induces cyclooxygenase-2 and microsomal prostaglandin $\mathrm{E}_{2}$ synthase in human lung fibroblasts: implications for lung inflammation and cancer. Am J Physiol Lung Cell Mol Physiol 2004; 287: L981-L991.

46 Chaudhuri R, Livingston E, McMahon AD, Thomson L, Borland W, Thomson NC. Cigarette smoking impairs the therapeutic response to oral corticosteroids in chronic asthma. Am J Respir Crit Care Med 2003; 168: 1308-1311. 